\title{
THE CHEMICAL COMPOSITION OF THE ESSENTIAL OIL AND VOLATILE COMPOUNDS FROM CARAWAY FRUIT (CARUM CARVI L.) EXTRACTED BY HEADSPACE-SOLID PHASE MICROEXTRACTION AND THE ANTIOXIDANT ACTIVITY
}

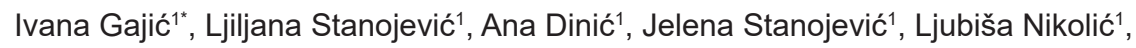
Vesna Nikolić ${ }^{1}$, Vesna Savić ${ }^{2}$

(ORIGINAL SCIENTIFIC PAPER) UDC 665.52:582.794.1:543.5

${ }^{1}$ Faculty of Technology, University of Niš, Leskovac, Serbia

2Department of Pharmacy, Faculty of Medicine, University of Niš, Niš, Serbia

The aim of this study was to isolate the essential oil from ripe and disintegrated caraway fruit by Clevenger-type hydrodistillation, to determine its qualitative and quantitative composition and to examine its antioxidant activity, as well as to determine the qualitative and quantitative chemical composition of the caraway volatile compounds extracted by HS-SPME technique. The essential oil from disintegrated caraway fruit was obtained by Clevenger-type hydrodistillation with hydromodulus 1:10 m/ during 180 minutes. Volatile compounds from caraway fruit were extracted by headspace-solid phase microextraction (HS-SPME) using $75 \mu \mathrm{m}$ fiber coated with Carboxen $® /$ Polydimethylsiloxane (PDMS). The qualitative and quantitative composition of the essential oil and volatile compounds was determined by gas chromatography coupled with mass spectrometry (GC-MS) and flame ionization detection (GC-FID). Twenty-seven different compounds were separated and identified in the essential oil. Twenty-six compounds were identified in the volatiles extracted by HS-SPME. The most abundant compounds in both examined samples were limonene and carvone. The content of carvone in the essential oil was $72 \%$, while the limonene content was $25.6 \%$. In the volatiles obtained by HS-SPME, the limonene was present with $72.1 \%$ and carvone with $24.6 \%$. The difference in the chemical composition is due to the oxidation of limonene to carvone during the hydrodistillation. The antioxidative activity of the caraway essential oil was determined by using DPPH assay immediately after adding DPPH radical and after 20 and 40 min of incubation with the radical. The caraway fruit essential oil showed a satisfactory antioxidant activity. The oil incubated for $40 \mathrm{~min}\left(\mathrm{EC}_{50}=4.6 \mathrm{mg} / \mathrm{cm}^{3}\right)$ showed the best antioxidant activity.
Keywords: caraway essential oil, headspace-solid phase microextraction, gas chromatography-mass spectrometry, carvone, limonene, antioxidant activity

\section{Introduction}

Caraway (Carum carvi L.) is a biennial herbaceous plant belonging to the Apiaceae family. It is one of the earliest cultivated plants in Asia, Africa and Europe [1]. The caraway plant grows best on sunny places in the soil rich in organic matter and can reach a height of 30 to $80 \mathrm{~cm}$. The fruit is a dark ellipsoidal schizocarp, which is often mistakenly called a seed. The schizocarp is 3-4 $\mathrm{mm}$ long and matures in early July. During the harvest, it divides into two mericarps with five slightly prominent ridges which are called seeds [2,3].

The use of caraway fruits dates back to ancient times when it was used in traditional medicine [1]. Today, it is a very popular spice that is widely used in nutrition and also in the pharmaceutical industry [4].

The yield of the essential oil obtained by extracting the ripe caraway fruit is $1-6 \%$ [5]. The most abundant components in this essential oil are cyclic monoterpenes $(R)$-carvone and D-limonene which represent 95\% of the total essential oil yield [4-7], and the carvone content is higher than limonene's [6,8]. Previous studies have shown that a higher yield of essential oil is obtained from the disintegrated plant material, but the carvone content in the oil is reduced by $15 \%$. Also, if the extraction of essential oil is performed from a fully ripe caraway fruit, the yield of the essential oil is higher with the higher carvone content by about $12 \%$ [5]. In addition to carvone and limonene, the caraway fruit essential oil contains about 30 other components. Some of them are $\alpha$-pinene, germacrene $\mathrm{D}$, cis-carveol, transcarveol, carvacrol, $\beta$-myrcene, apiol, linalool, dihydrocarvone, $p$-cymene, $\mathrm{y}$-terpinene, which are present in a smaller percentage $[5,6,9,10]$.

Many studies have examined and confirmed the strong antioxidant activity of caraway essential oil, but it also has other biological activities [8,11-13]. By examining the effect of the caraway essential oil on induced hy-

\footnotetext{
*Author address: Ivana Gajić, Faculty of Technology, University of Niš, Bulevar Oslobođenja 124, 16000 Leskovac, Serbia.

E-mail: ivananikolic1991@yahoo.com

The manuscript received: May, 15, 2020.

Paper accepted: June, 12, 2020.
} 
perglycemia in rats, Abou El-Soud et al. (2014) showed that its use significantly reduced oxidative stress and the release of reactive oxygen species (ROS) in diabetes, and thus led to a nephroprotective effect [9]. The hepatoprotective effect of the caraway essential oil can be explained by the inhibition of lipid peroxidation $[11,14]$. The caraway essential oil has antimicrobial activity and inhibits the growth of bacteria and fungi, for which carvone is responsible $[15,16]$. The pronounced antimicrobial activity of the caraway essential oil has been proven against two medically important pathogens, Candida albicans and Escherchia coli [17], while the oil also has a good effect against Staphylococcus aureus, Salmonella enterica, Aspergilus niger and Penicillium spp. [18]. In addition, the caraway fruit essential oil exhibits antiulcerogenic $[19,20]$, spasmolytic, insecticidal and anticonvulsant effects [18,21].

Fang et al. (2010) isolated and purified the major components of the caraway essential oil, $(R)$-carvone and D-limonene, and proved that these compounds are potent fumigants [22]. In addition to being considered a carrier of antimicrobial activity, carvone also has antimanic-like activity, and can be used as an adjuvant in the treatment of brain tumors. Carvacrol has a significant activity against Escherichia coli and completely inhibits the growth of Penicillium citrinum [12]. The anticancer and antiproliferative activity of COLO 205 coIon cancer cell lines is mostly attributed to apiol and its analogue, which can also be found in the caraway fruit essential oil [18].

The previous research indicates that obtaining of the essential oil using the method of supercritical fluid extraction (SFE) from the whole caraway fruit is not suitable, but that it should be applied only to disintegrated caraway fruit [5]. According to the 8th European Pharmacopoeia, the prescribed method for isolating the essential oil from caraway fruit is hydrodistillation. Ghafari et al. (2014) isolated the essential oil from the ground caraway fruit by hydrodistillation using Clevenger-type apparatus for $3 \mathrm{~h}$, and then analyzed the isolated oil by GC-MS method [10]. Also, the influence of the ultrasonic treatment of the caraway fruit before the isolation of the essential oil by hydrodistillation was investigated. The results showed that the ultrasound treatment allows a rapid release of the essential oil, almost $80 \%$ after only 30 minutes of the extraction, while for the same amount of the essential oil from the untreated caraway fruit takes 90 minutes [23]. Meshkatalsadat et al. (2012) were first to apply the ultrasonic assist with headspace solid phase microextraction (UA-HS-SPME) to obtain volatile organic compounds from the caraway fruit originating from Iran. This method proved to be significant because it requires a much shorter extraction time, a smaller amount of the sample and the simpler sample preparation with the minimal loss of volatile compounds [24].

The aim of this study was to isolate the essential oil from the ripe and disintegrated caraway fruit by Clevenger-type hydrodistillation, to determine the qualita- tive and quantitative composition of the isolated oil and to examine its antioxidant activity. Another objective of this study was to determine the qualitative and quantitative chemical composition of the caraway volatile compounds extracted by HS-SPME technique.

\section{Experimental}

\section{Plant materials}

Ripe caraway fruits were purchased from the local health food store (manufacturer: Institute of Medicinal Plants Research "Dr Josif Pančić", Belgrade). The required amount of the caraway fruit was ground in an electric mill (Braun Aromatic KSM2) right before hydrodistillation.

\section{Chemicals}

Butylated hydroxytoluene (BHT), L-ascorbic acid, 2,2-diphenyl-1-picrylhydrazyl (Sigma Chemical Company, St. Louis, USA), ethanol, 96\% (Centrohem, Zemun, Serbia). Other chemicals used were of p.a. purity grade.

\section{Essential oil isolation}

The essential oil was obtained from the disintegrated caraway fruit by Clevenger-type hydrodistillation, with hydromodulus $1: 10 \mathrm{~m} / \mathrm{V}$ during $180 \mathrm{~min}$. The amount of the essential oil was determined per $100 \mathrm{~g}$ of the dried plant material. The isolated essential oil $\left(1.43 \mathrm{~cm}^{3}\right)$ was dried over anhydrous sodium sulfate and kept in the dark bottle at $4{ }^{\circ} \mathrm{C}$ until analysis.

GC-MS and GC-FID analysis of caraway essential oil GC-MS analysis of the essential oil obtained from the caraway fruit was performed on Agilent Technologies 7890B gas chromatograph, coupled with inert, selective 5977A mass detector of the same company. The essential oil obtained was dissolved in diethyl ether. One $\mu$ of the prepared solution was injected in split/ splitless inlet set at $250^{\circ} \mathrm{C}$ in $20: 1$ split mode. The components were separated on weakly polar, silica capillary column, HP-5MS (5\% diphenyl- and 95\% dimethylpolysiloxane, $30 \mathrm{~m} \times 0.25 \mathrm{~mm}, 0.25 \mu \mathrm{m}$ film thickness; Agilent Technologies, USA). Helium was used as the carrier gas, at a constant flow rate of $1 \mathrm{~cm}^{3} / \mathrm{min}$. The oven temperature was programmed from $50^{\circ} \mathrm{C}$ for $2.25 \mathrm{~min}$ utes and then increased to $290{ }^{\circ} \mathrm{C}$ at the rate of $4{ }^{\circ} \mathrm{C} / \mathrm{min}$. Separated components were further analyzed by mass spectrometer. Temperatures of the MSD transfer line, ion source and quadruple mass analyzer were set at $300^{\circ} \mathrm{C}, 230^{\circ} \mathrm{C}$ and $150^{\circ} \mathrm{C}$, respectively. The ionization voltage was $70 \mathrm{eV}$ and the mass detection was done in the Scan mode, in $\mathrm{m} / \mathrm{z}$ range from 35 to 650 .

Data processing was performed using MSD ChemStation (revision F.01.00.1903) in combination with AMDIS (revision 2.70) and NIST MS Search (version $2.0 \mathrm{~g})$ softwares (Agilent Technologies, USA). Retention indices of the components from the sample were experimentally determined using a homologous series 
of $\mathrm{n}$-alkanes from $\mathrm{C}_{8}-\mathrm{C}_{20}$ as standards, analyzed under identical GC/MS and GC/FID conditions. The identification of compounds was based on the comparison of experimentally obtained retention indices ( $\mathrm{Rl}^{\text {exp }}$-Table 1 ) with those found in the literature [25], as well as on the comparison of El mass spectra of the essential oil components with data from Willey 6, NIST11 and RTLPEST 3 mass spectra libraries. The percentage content of a particular component in the essential oil was determined on the basis of Area Percent Report (uncalibrated calculation procedure) generated by Agilent ChemStation software.

Sample preparation and HS-SPME extraction

Volatile compounds from the caraway fruit were extracted by headspace-solid phase microextraction (HSSPME). Their qualitative and quantitative composition was determined by gas chromatography coupled with mass spectrometry (GC-MS) and flame ionization detection (GC-FID), respectively.

The manual SPME fiber holder, as well as the fiber coated with Carboxen®/Polydimethylsiloxane (PDMS) $(75 \mu \mathrm{m}$ thickness) were purchased from Supelco (Bellefonte, PA, USA). Before the analysis, the SPME fiber was conditioned for $5 \mathrm{~min}$ in the GC injector set at $250^{\circ} \mathrm{C}$. One gram of dried caraway fruit was disintegrated in an electrical mill (Braun Aromatic KSM 2), placed in $10 \mathrm{~cm}^{3}$ vial and closed. The fiber was exposed to the headspace of the sample for $20 \mathrm{~min}$ at controlled laboratory temperature $\left(23^{\circ} \mathrm{C}\right)$. After extraction, the needle of the SPME fiber holder was inserted into the GC injector and the fiber was directly exposed to the injector port set at $250{ }^{\circ} \mathrm{C}$ in the 20:1 split mode. After the analysis was finished, the fiber was thermally desorbed at $250{ }^{\circ} \mathrm{C}$ for $10 \mathrm{~min}$.

GC-MS and GC-FID analysis of volatile compounds from caraway fruit

The chromatographic analysis of the volatiles from the caraway fruit was performed on the same gas chromatograph used and described for the essential oil. Helium, at a constant flow rate of $1 \mathrm{~cm}^{3} / \mathrm{min}$, was used as a carrier gas. The GC oven temperature was held for 2 min at $40{ }^{\circ} \mathrm{C}$, increased to $250^{\circ} \mathrm{C}$ at the rate of $7{ }^{\circ} \mathrm{C} /$ min, and finally held at $250{ }^{\circ} \mathrm{C}$ for $2 \mathrm{~min}$. The total run time was $34 \mathrm{~min}$. Mass spectrometer and FID detector conditions were set as previously described for the essential oil analysis.

The identification of the volatiles was based on the comparison of El mass spectra with data from Willey 6 , NIST11 and RTLPEST 3 mass spectra libraries. In order to confirm the identification, linear retention indices were calculated $\left(\mathrm{RI}^{\mathrm{exp}}\right.$ - Table 1) using the retention times of standard alkane mixture from $\mathrm{C}_{8}-\mathrm{C}_{20}$ obtained and compared with those found in literature [25] (Rlit Table 1). The percentage composition determination of a particular component was based on the Area Percent Report generated by Agilent ChemStation software.
Antioxidative activity

DPPH assay

The DPPH method was used to examine the antioxidant activity of the caraway fruit essential oil. Working solutions of the caraway essential oil in the concentration range of $0.2-50 \mathrm{mg} / \mathrm{cm}^{3}$ were prepared by diluting the stock solution $\left(50 \mathrm{mg} / \mathrm{cm}^{3}\right)$ with ethanol. The $1 \mathrm{~cm}^{3}$ of ethanolic DPPH radical solution $\left(3 \times 10^{-4} \mathrm{~mol} / \mathrm{dm}^{3}\right)$ was added to $2.5 \mathrm{~cm}^{3}$ of the prepared essential oil solutions. The absorption was measured at $517 \mathrm{~nm}$ immediately after adding the DPPH radical and after the incubation with radical for 20 and 40 minutes. The absorption at $517 \mathrm{~nm}$ was also determined for the ethanolic solution of DPPH radical $\left(1 \mathrm{~cm}^{3}\right.$ of the DPPH radical of the given concentration with $2.5 \mathrm{~cm}^{3}$ of ethanol) and for the ethanolic solutions of the essential oil $\left(2.5 \mathrm{~cm}^{3}\right.$ of the essential oil solution with $1 \mathrm{~cm}^{3}$ of ethanol). Free radical scavenging capacity of the essential oil was calculated according to the equation 1 [26]:

DPPH radical scavenging capacity $(\%)=100-\left[\left(A_{S}-A_{B}\right) \times \frac{100}{A_{C}}\right]$

AS - Absorption of the "sample" at $517 \mathrm{~nm}$. "Sample" was the ethanolic solution of the essential oil treated with DPPH radical solution.

AB - Absorption of the "blank" at $517 \mathrm{~nm}$. "Blank" was the ethanolic solution of the essential oil which is not treated with DPPH radical solution.

AC - Absorption of the "control" at $517 \mathrm{~nm}$. "Control" was the ethanolic solution of the DPPH radical.

All absorptions were measured on UV-2100 Spectrophotometer (Cole Parmer, France).

\section{Results and discusion}

GC/FID chromatogram of the essential oil isolated from the disintegrated caraway fruit is shown in Figure 1. Twenty-seven compounds, representing $99.8 \%$ of the total oil composition, were separated and identified in the caraway essential oil. The peak at the retention time of 13.23 min corresponded to limonene and its content in the essential oil was $25.6 \%$. The peak at the retention time of 21.06 min corresponded to carvone which is the most abundant compound in the oil (72.0\%). Other components were present in a much lower percentage. The essential oil composition in terms of the main components content is in accordance with the available literature data $[27,28]$. In the research by Rasooli et al. [27], caraway essential oils from different countries also had the highest content of carvone and limonene, in the range of $61.58-77.35 \%$ and $16.15-29.11 \%$, respectively, depending on the origin of the plant material and the method applied for the essential oil isolation. Other components in these essential oils from the groups of monoterpene hydrocarbons, aldehydes, ketones, oxygenated monoterpenes and sesquiterpene hydrocarbons were present in a much smaller percentage, which is in accordance with our results. 


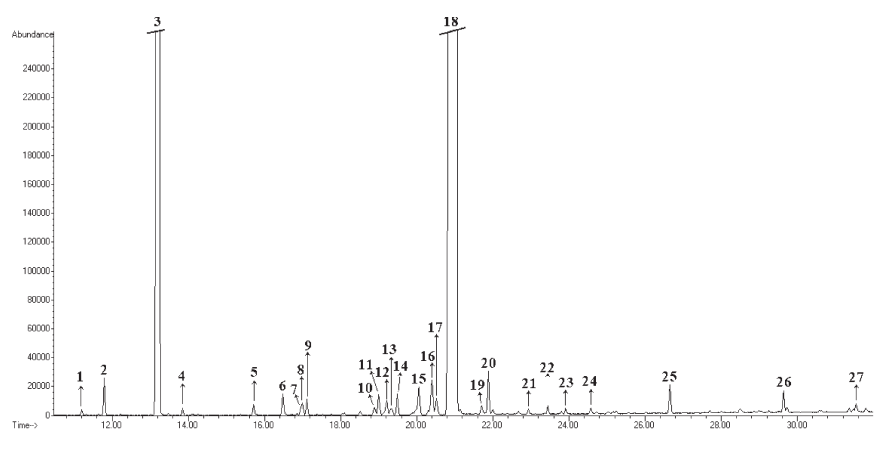

Figure 1. GC-FID chromatogram of the caraway essential oil

The qualitative and quantitative composition of the caraway fruit essential oil (names and molecular formulas of the identified compounds, their retention times ( $\mathrm{min}$ ), experimentally determined retention indices and retention indices from literature, as well as the methods of identification and content (\%) is presented in Table 1.

Table 1. Chemical composition of the caraway (Carum carvi L.) essential oil

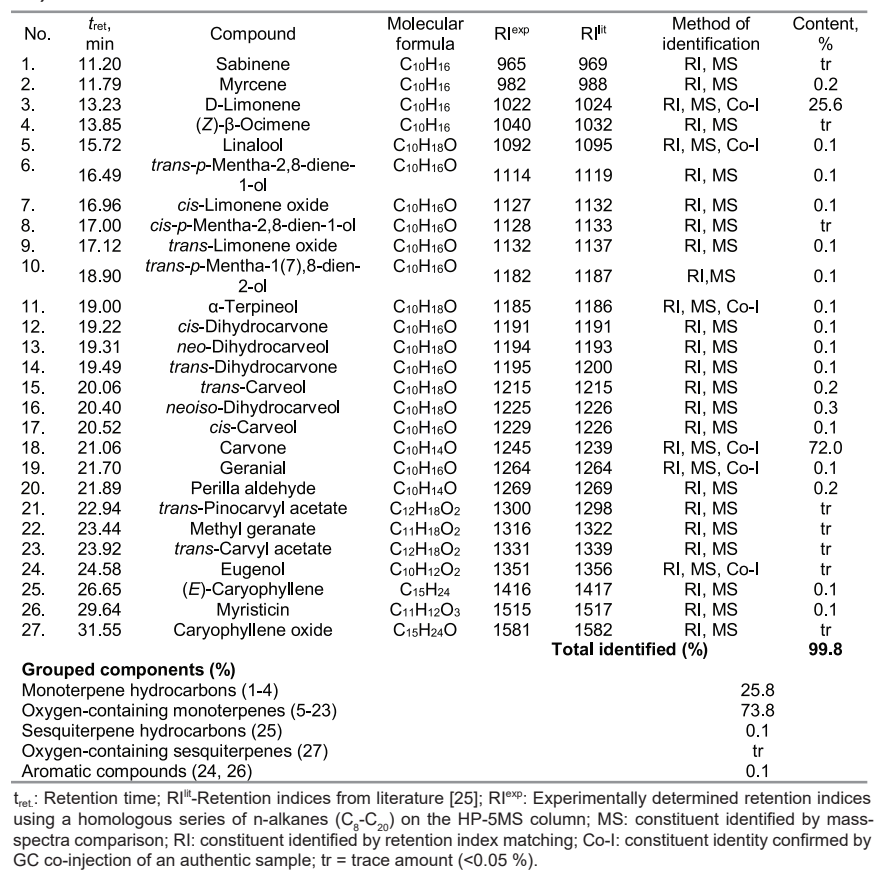

The identified compounds in the caraway fruit essential oil were divided in five groups: monoterpene hydrocarbons, oxygen-containing monoterpenes, sesquiterpene hydrocarbons, oxygen-containing sesquiterpenes and aromatic compounds. The most abundant group was oxygen-containing monoterpenes comprising up to $73.8 \%$, followed by monoterpene hydrocarbons with $25.8 \%$ of the total oil composition. The content of the other groups of compounds was much lower.

GC-FID chromatogram of the volatile compounds extracted from the caraway fruit is shown in Figure 2. Twenty-six different compounds were separated and identified. The peaks at the retention times of 11.79 , 16.45 and 10.82 min corresponded to limonene, carvone and myrcene, and their content was $72.1,24.6$ and $1 \%$, respectively.

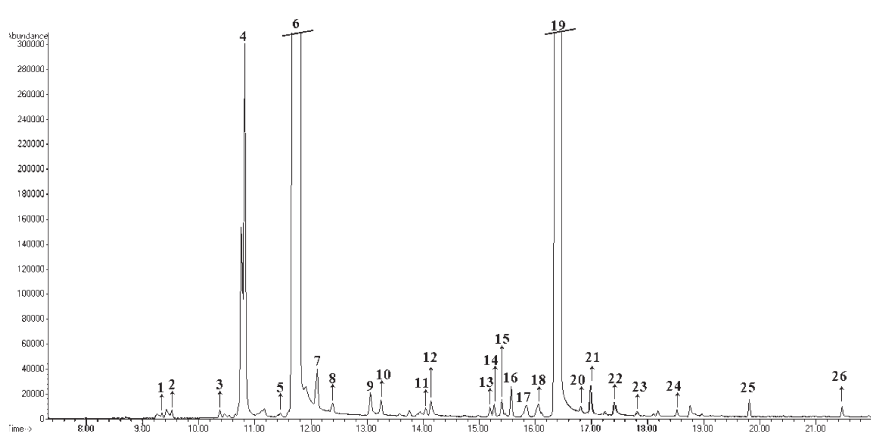

Figure 2. GC-FID chromatogram of volatile compounds from caraway fruit

The qualitative and quantitative composition of caraway fruit volatiles (names and molecular formulas of the identified compounds, their retention times ( $\mathrm{min}$ ), experimentally determined retention indices and retention indices from literature, as well as methods of identification and content (\%)) is presented in Table 2 .

Table 2. Chemical composition of volatile compounds from caraway (Carum carvi L.) fruit

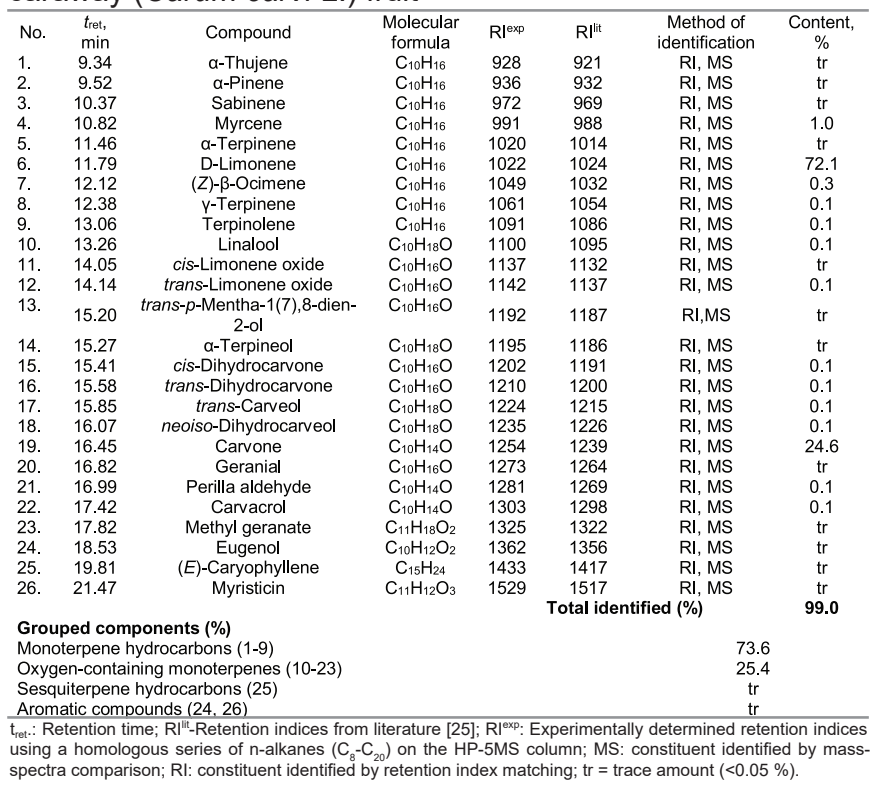

The most abundant group of compounds was monoterpene hydrocarbons comprising up to $73.6 \%$, followed by oxygen-containing monoterpenes with $25.4 \%$ of the total volatile compounds composition. Sesquiterpene hydrocarbons and aromatic compounds were present in trace amounts. The comparative chemical composition analysis of the essential oil and volatile compounds from caraway fruit showed that carvone $(72.0 \%)$ is a dominant compound in the essential oil, while limonene $(72.1 \%)$ is a major compound in the volatiles extracted by HSSPME. The difference in the chemical composition between the essential oil and volatile compounds is a result 
of the oxidation of limonene to carvone during the hydrodistillation [29]. Therefore, the content of carvone was much higher in the essential oil than in the caraway fruit. Another reason for a different chemical composition of the essential oil and volatile compounds of the caraway fruit can be a possible loss of easily volatile compounds during hydrodistillation. Mohammadhosseini et al. [30] analyzed the chemical composition of the essential oil and volatile compounds of Eryngium bungei Bioss. by using GC-MS and HS-SPME methods and showed that essential oil contains carvon, while volatiles contain limonene, which is in accordance with our results. The structures of these two dominant compounds are given in Figure 3.

a)<smiles>C=C(C)C1CC=C(C)C(=O)C1</smiles>

b)

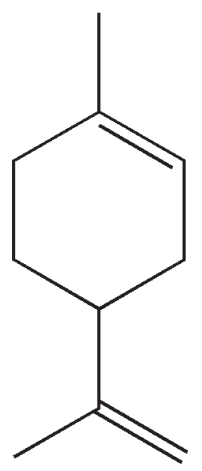

Figure 3. Structures of (a) carvone and (b) limonene

The antioxidant activity of the isolated caraway essential oil was determined by using DPPH assay. The DPPH is a stable radical with a free delocalized electron on a nitrogen atom, which gives purple color with an absorption in the ethanol solution at $517 \mathrm{~nm}$. By receiving proton from the antioxidant, DPPH radical is reduced to diphenylpicrylhydrazine, which is yellow in color. The result of the DPPH reduction is the decrease of the absorption at $517 \mathrm{~nm}$, which is proportional to the antioxidant activity of the examined substance (Figure 4).

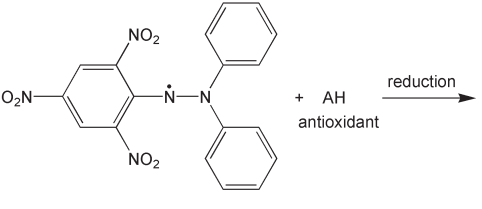

DPPH (purple)

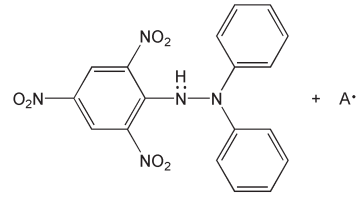

DPPHH (yellow)
Figure 4. The reduction of free 2,2-diphenyl-1-picrylhydrazyl (DPPH) radical to 2,2-diphenyl-1-picrylhydrazine (DPPHH)

DPPH assay is the most commonly used method for testing the antioxidant activity of many natural antioxidants because it is fast, reproducible and sensitive. The use of antioxidants is increasing due to their ability to neutralize free radicals that occur in oxidative stress and the presence of which can lead to a significant cell damage. The $\mathrm{EC}_{50}$ value is an important parameter that represents the concentration of the substance that causes $50 \%$ loss of DPPH activity. Based on the obtained values for $\mathrm{EC}_{50}$, the ability of the substance to neutralize free radicals can be estimated $[31,32]$.

The antioxidant activity of the caraway fruit essential oil, immediately after adding DPPH radical and after 20 and $40 \mathrm{~min}$ of incubation with the radical is shown in Figure 5. After incubation, the same essential oil concentration neutralized a higher percentage of DPPH radical. The essential oil at the concentration of $50 \mathrm{mg} / \mathrm{cm}^{3}$ neutralized $90 \%$ of DPPH radical after 40 min of incubation, $85 \%$ after $20 \mathrm{~min}$ of incubation, and only $20 \%$ without incubation.

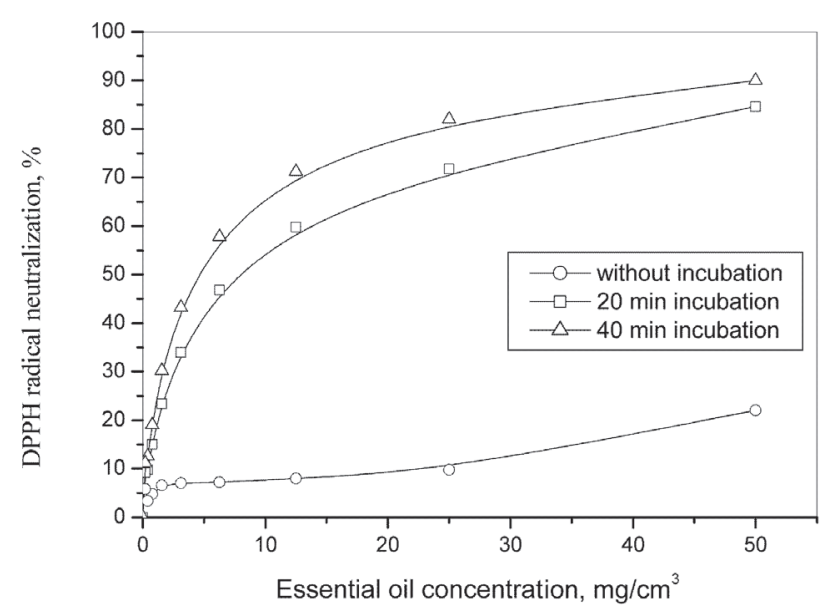

Figure 5. Antioxidant activity of the caraway fruit essential oil

The $\mathrm{EC}_{50}$ value for the sample incubated for $40 \mathrm{~min}$ utes was $4.6 \mathrm{mg} / \mathrm{cm}^{3}$, while this value was greater for the sample incubated for 20 minutes $\left(7.9 \mathrm{mg} / \mathrm{cm}^{3}\right)$. This showed that with longer incubation, a better antioxidant activity was achieved. $\mathrm{EC}_{50}$ values for the standards Lascorbic acid and BHT after 20 min of incubation were significantly lower, $0.003 \mathrm{mg} / \mathrm{cm}^{3}$ and $0.02 \mathrm{mg} / \mathrm{cm}^{3}$, respectively, which is in accordance with literature data [33]. The presented results showed that the essential oil has the antioxidant activity, but it is weaker than the antioxidant activity of L-ascorbic acid and BHT.

A review of the available literature showed several reports on the antioxidant activity of the caraway essential oil $[8,11,12,34]$. However, a direct comparison of our results with previously reported findings was not possible due to different experimental protocols and different ways of expressing the antioxidant activity.

\section{Conclusion}

The most abundant groups of compounds in the caraway essential oil and volatile compounds extracted by HS-SPME were monoterpene hydrocarbons and oxygen-containing monoterpenes. Carvone was the most abundant compound in the essential oil $(72 \%)$, while limonene was the major compound in the volatiles obtained by HS-SPME (72.1\%). A lower limonene content in the essential oil was a result of its oxidation to carvone during hydrodistillation. The caraway fruit essential oil 
showed a satisfactory antioxidant activity, especially after incubation with radical for $40 \mathrm{~min}\left(\mathrm{EC}_{50}=4.6 \mathrm{mg} / \mathrm{cm}^{3}\right)$. At the concentration of $50 \mathrm{mg} / \mathrm{cm}^{3}$, the essential oil neutralized $90 \%$ of the free DPPH radical. Compared to L-ascorbic acid and $\mathrm{BHT}$, the caraway fruit essential oil is a weaker antioxidant.

\section{Acknowledgements}

The Republic of Serbia - Ministry of Education, Science and Technological Development, Program for financing scientific research work, number 451-0368/2020-14/200133.

\section{Abbreviations and symbols}

BHT - Butylated hydroxytoluene

DPPH - 2,2-diphenyl-1-picrylhydrazyl

DPPHH - 2,2-diphenyl-1-picrylhydrazine

GC-FID - Gas chromatography coupled with flame ionization detection

GC-MS - Gas chromatography coupled with mass spectrometry

HS-SPME - Headspace-solid phase microextraction

PDMS - Polydimethylsiloxane

ROS - Reactive oxygen species

UA-HS-SPME - Ultrasonic assist with headspace solid phase microextraction

\section{References}

[1] R. K. Johri, Cuminum cyminum and Carum carvi: An update, Pharmacognosy Reviews, 5(9) (2011) 63 - 72.

[2] P. Agrahari, D. K. Singh, A review on the pharmacological aspects of Carum carvi, Journal of Biology and Earth Sciences, 4(1) (2014) M1 - M13.

[3] A. K. Sachan, D. R. Das, M. Kumar, Carum carvi-An important medicinal plant, Journal of Chemical and Pharmaceutical Research, 8(3) (2016) 529 - 533.

[4] A. Raal, E. Arak, A. Orav, The content and composition of the essential oil found in Carum carvi L. commercial fruits obtained from different countries, Journal of Essential Oil Research, 24(1) (2012) 53 - 59.

[5] J. Sedláková, B. Kocourková, L. Lojková, V. Kubán̆, The essential oil content in caraway species (Carum carvi L.). Horticultural Science, 30(2) (2003) 73 - 79.

[6] K. Seidler-Lozykowska, M. Baranska, R. Baranski, D. Krol, Raman analysis of caraway (Carum carvi L.) single fruits. Evaluation of essential oil content and its composition. Journal of Agricultural and Food Chemistry, 58(9) (2010) $5271-5275$.

[7] N. S. lacobellis, P. Lo Cantore, F. Capasso, F. Senatore, Antibacterial activity of Cuminum cyminum L. and Carum carvi L. essential oils, Journal of Agricultural and Food Chemistry, 53(1) (2005) 57 - 61.

[8] I. Samojlik, N. Mimica-Dukić, N. Lakic, A. Nikolic, M. Bogavac, B. Bozin, Antioxidant activities of Carum carvi L. and Coriandrum sativum L., Apiaceae essential oils, Planta Medica, 74(09) (2008) PI26.

[9] N. H. Abou El-Soud, N. A. El-Lithy, G. El-Saeed, M. S. Wahby, M. Y. Khalil, F. Morsy, N. Shaffie, Renoprotective effects of caraway (Carum carvi L.) essential oil in streptozotocin induced diabetic rats. Journal of Applied Pharmaceutical Science, 4(2) (2014) 27 - 33.

[10] Z. Ghafari, A. Alizadeh, R. B. Samani, Antimicrobial activity and essential oil composition of Cuminum cyminum $L$. and Carum carvi L. seeds from Iran. International Journal of Biosciences, 6 (2014) 153 - 159.

[11] I. Samojlik, N. Lakic, N. Mimica-Dukic, K. Đaković-Švajcer, B. Bozin, Antioxidant and hepatoprotective potential of essential oils of coriander (Coriandrum sativum L.) and caraway (Carum carvi L.)(Apiaceae), Journal of Agricultural and Food Chemistry, 58(15) (2010) 8848 8853.

[12] L. De Martino, V. De Feo, F. Fratianni, F. Nazzaro, Chemistry, antioxidant, antibacterial and antifungal activities of volatile oils and their components, Natural Product Communications, 4(12) (2009) 1741 - 1750.

[13] F. Darougheh, M. Barzegar, M. Ali Sahari, Antioxidant and anti-fungal effect of caraway (Carum Carvi L.) essential oil in real food system, Current Nutrition \& Food Science, 10(1) (2014) $70-76$.

[14] H. Özbek, N. İ. Kırmızı, N. Cengiz, E. Erdoğan, Hepatoprotective effects of coriandrum sativum essential oil against acute hepatotoxicity induced by carbon tetrachloride on rats, ACTA Pharmaceutica Sciencia, 54(1) (2016) 35 - 40.

[15] K. Seidler-Łożykowska, B. Kędzia, E. Karpińska, J. Bocianowski, Microbiological activity of caraway (Carum carvi L.) essential oil obtained from different origin, Acta Scientiarum. Agronomy, 35(4) (2013) 495 - 500.

[16] A. Simic, A. Rančic, M. D. Sokovic, M. Ristic, S. GrujicJovanovic, J. Vukojevic, P. D. Marin, Essential oil composition of Cymbopogon winterianus and Carum carvi and their antimicrobial activities, Pharmaceutical Biology, 46(6) (2008) 437 - 441.

[17] Z. Ghafari, A. Alizadeh, R. B. Samani, Antimicrobial activity and essential oil composition of Cuminum cyminum $\mathrm{L}$. and Carum carvi L. seeds from Iran, International Journal of Biosciences, 6 (2014) 153 - 159.

[18] M. Akram, M. Azhar, N. Anjum, N.Quddusi, Phytopharmacology of unani drug Zeerah Siyah (Carum Carvi Linn)-A review, Journal of Pharmacognosy and Phytochemistry, 8(1) (2019) 2772 - 2782.

[19] S. Baananou, E. Bagdonaite, B. Marongiu, A. Piras, S. Porcedda, D. Falconieri, N. Boughattas, Extraction of the volatile oil from Carum carvi of Tunisia and Lithuania by supercritical carbon dioxide: chemical composition and antiulcerogenic activity, Natural Product Research, 27(22) (2013) 2132 - 2136.

[20] A. Keshavarz, M. Minaiyan, A. Ghannadi, P. Mahzouni, Effects of Carum carvi L.(Caraway) extract and essential oil on TNBS-induced colitis in rats, Research in Pharmaceutical Sciences, 8(1) (2013) 1 - 8.

[21] A. Showraki, M. Emamghoreishi, S. Oftadegan, Anticonvulsant effect of the aqueous extract and essential oil of Carum carvi L. seeds in a pentylenetetrazol model of seizure in mice, Iranian Journal of Medical Sciences, 41(3) (2016) 200 - 208.

[22] R. Fang, C. H. Jiang, X. Y. Wang, H. M. Zhang, Z. L. Liu, L. Zhou, Z. W. Deng, Insecticidal activity of essential oil of Carum carvi fruits from China and its main components against two grain storage insects, Molecules, 15(12) (2010) 9391 - 9402.

[23] K. Assami, D. Pingret, S. Chemat, B. Y. Meklati, F. Chemat, 
Ultrasound induced intensification and selective extraction of essential oil from Carum carvi L. seeds, Chemical Engineering and Processing: Process Intensification, 62 (2012) 99 - 105.

[24] M. H. Meshkatalsadat, S. A. B. A. H. Salahvarzi, R. Aminiradpoor, A. Abdollahi, Identification of essential oil constituents of caraway (Carum carvi) using ultrasonic assist with headspace solid phase microextraction (UA-HS-SPME), Digest Journal of Nanomaterials and Biostructures, 7(2) (2012) 637 - 640.

[25] R. P. Adams, Identification of essential oil components by gass chromatography/mass spectrometry, 4th Ed. Allured Publishing Corporation, Illinois 2007.

[26] J. S. Stanojević, Lj. P. Stanojević, D. J. Cvetković, B. R. Danilović, Chemical composition, antioxidant and antimicrobial activity of the turmeric essential oil (Curcuma longa L.), Advanced Technologies, 4(2) (2015) 19 - 25.

[27] I. Rasooli, A. Allameh, in Essential Oils in Food Preservation, Flavor and Safety, V. R. Preedy Ed., Ch. 32 Caraway (Carum carvi L.) Essential Oils, Academic Press, New York, 2016, p 287-293.

[28] S. K. Malhotra, in Handbook of Herbs and Spices, Edition: 2, K.V. Peter Ed., Ch. 11 - Caraway, Woodhead Publishing, 2012, p. 225-248.

[29] Y. Li, Y. Yang, D. Chen, Z. Luo, W. Wang, Y. Ao, L. Zhang, Z. Yan, J. Wang, Liquid-Phase Catalytic Oxidation of Limonene to Carvone over ZIF-67(Co), Catalysts, 9 (4) (2019) No 374 (p. 1 - 13).
[30] M. Mohammadhosseini, B. Mahdavi, H. Akhlaghi, Characterization and chemical composition of the volatile oils from aerial parts of Eryngium bungei Bioss.(Apiaceae) by using traditional hydrodistillation, microwave assisted hydrodistillation and head space solid phase microextraction methods prior to $\mathrm{GC}$ and GC/MS analyses: A comparative approach, Journal of Essential Oil Bearing Plants, 16(5) (2013) 613 - 623.

[31] W. Brand-Williams, M. E. Cuvelier, C. Berset, Use of a free radical method to evaluate antioxidant activity, LWT Food Science and Technology, 28(1995) 25 - 30.

[32] V. Bondet, W. Brand-Williams, C. Berset, Kinetics and mechanisms of antioxidant activity using the DPPH $\bullet$ free radical method, LWT Food Science and Technology, 30(1997) $609-615$.

[33] Lj. P. Stanojević, A. S. Zdravković, M. Z. Stanković, M. D. Cakić, V. D. Nikolić, D. P. Ilić, Antioksidativna aktivnost vodeno-etanolnih ekstrakata iz lista koprive (Urtica dioica L.), Savremene tehnologije, 2(1) (2013) 51 - 59.

[34] A. Trifan, A. C. Aprotosoaie, O. Cioanca, M. Hancianu, A. Jitareanu, E. Gille, A. Miron, Antioxidant activity of essential oil from Carum Carvi L. cultivated in northeastern Romania, The Medical-Surgical Journal, 120(3) (2016) 732 - 736.

Izvod

\section{HEMIJSKI SASTAV ETARSKOG ULJA I ISPARLJIVIH KOMPONENTI IZ PLODA KIMA (CARUM CARVI L.) EKSTRAHOVANIH MIKROEKSTRAKCI- JOM NA ČVRSTOJ FAZI I ANTIOKSIDATIVNA AKTIVNOST}

Ivana Gajić ${ }^{*}$, Ljiljana Stanojević ${ }^{1}$, Ana Dinić ${ }^{1}$, Jelena Stanojević1 ${ }^{1}$ Ljubiša Nikolić1, Vesna Nikolić ${ }^{1}$, Vesna Savić

${ }^{1}$ Tehnološki fakutet, Univerzitet u Nišu, Leskovac, Srbija

2Odsek za farmaciju, Medicinski fakultet, Univerzitet u Nišu, Niš, Srbija

Cilj rada bio je izolacija etarskog ulja iz zrelog i samlevenog ploda kima hidrodestialcijom po Clevenger-u, određivanje njegovog kavalitativnog i kvantitativnog sastava i antioksidativne aktivnosti, kao i određivanje kvalitativnog i kvantitativnog hemijskog sastava isparljivih komponenti dobijenih iz ploda kima mikroekstrakcijom na čvrstoj fazi. Etarsko ulje iz samlevenog ploda kima dobijeno je hidrodestilacijom po Clevenger-u pri solvomodulu 1:10, $\mathrm{m} / \mathrm{v}$ u trajanju od $180 \mathrm{~min}$. Isparljive komponente iz ploda kima ekstrahovane su tehnikom mikroekstrakcije na čvrstoj fazi (HS-SPME) sa $75 \mu \mathrm{m}$ polidimetilsiloksanovim (PDMS) vlaknom presvučenim Carboxen®-om. Kvalitativni i kvantitativni sastav etarskog ulja i isparljivih komponenata određen je primenom gasne hromatografije kuplovane sa masenom spektrometrijom (GC-MS) i plameno-jonizacionim detektorom (GC-FID). Analizom etarskog ulja razdvojeno je i identifikovano 27 jedinjenja, a u isparljivim komponentama iz ploda kima dobijenim mikroekstrakcijom na čvrstoj fazi (HS-SPME) je identifikovano 26 jedinjenja. Najzastupljenija jedinjenja u oba ispitivana uzorka su limonen i karvon. U etarskom ulju sadržaj karvona je $72 \%$ dok je limonen zastupljen sa $25,6 \%$. U isparljivim jedinjenjima dobijenim ekstrakcijom HS-SPME limonen je zastupljen sa $72,1 \%$, a karvon sa $24,6 \%$. Razlika u hemijskom sastavu nastaje najverovatnije zbog oksidacije limonena do karvona tokom hidrodestilacije. Antioksidativna aktivnost etarskog ulja ploda kima utvrđena je DPPH metodom odmah nakon dodavanja DPPH radikala i nakon 20 i 40 min inkubacije sa radikalom. Etarsko ulje ploda kima pokazalo je zadovoljavajuću antioksidativnu aktivnost. Najbolje antioksidativno delovanje pokazuje etarsko ulje inkubirano 40 min $\left(E_{50}\right.$ $=4,6 \mathrm{mg} / \mathrm{cm}^{3}$ ).
(ORIGINALNI NAUČNI RAD) UDK 665.52:582.794.1:543.5

Ključne reči: Etarsko ulje kima, HSSPME, GC-MS, karvon, limonen, antioksidativna aktivnost 